\title{
Consumerism in Contemporary China
}

\author{
Karl Gerth
}

Why have the values of consumerism become predominant in the contemporary world? This chapter explores the rise of consumerism through the recent history of China and the spread of its defining value-you are what you consume-through two related arguments. First, consumerism is embedded in industrialization itself. Second, consumerism has not spread spontaneously. The history of China since the Communist Revolution in 1949 suggests that every industrializing state, whether "capitalist" or "socialist," has played a critical role in spreading consumerist values. Political economies around the world-even "socialist" ones-have helped spread consumerism over many decades. Because humans and their institutionsnot "human nature"-create consumerism, the possibility of promoting non-consumerist values such as egalitarianism, civic mindedness, and spirituality exists. However, the history of consumerism also reveals itself to be a formidable foe to such alternative values. ${ }^{l}$

Modern consumerism spread as part of industrialization. Industrialization and consumerism have depended on each other. Observers often

${ }^{\mathrm{l}}$ For providing a forum and critical commentary, the author thanks Tanweer Akram and the other participants at the conference, "Faith and Finance," the University of St. Thomas, Minneapolis (July 25, 2018).

K. Gerth $(\bowtie)$

Department of History, University of California, San Diego, CA, USA

(C) The Author(s) 2020

T. Akram and S. Rashid (eds.), Faith, Finance, and Economy, https://doi.org/10.1007/978-3-030-38784-6_5 
overlook this dependence. Modern history usually focuses on the production side of this relationship: how people used new technologies and fossil fuels to improve productivity and expand production, that is, how countries industrialized. Studying consumerism shifts the traditional focus from production to consumption, from the supply side to the demand side of industrialization. Endless demand for mass-produced things has been assumed by historians who have focused on industrialization as a story of overcoming the limits of production with fossil fuels and new technologies. But a simultaneous expansion of demand alongside production had to occur. Industrial capitalism needed people (reconceptualized as "consumers") to want newer and more products. The history of consumerism explores the challenge of getting people to value learning about and attempting to acquire ever-more things. ${ }^{2}$ To give one example, modern advertising became "modern" because it relied heavily on images and implied stories rather than text and information. ${ }^{3}$ Advertising informed "consumers" not simply that a given product existed and had various specific uses but rather that acquisition of a product allowed one to construct and communicate an identity through its consumption. Consumerism valued the use of things rather than, say, actions or relationships to tell the world (and oneself) who one is.

Supporters of consumerist values emphasize how the consumption of things enables self-expression and empowerment, what scholars refer to as "agency." To invoke a famous US advertising slogan, one could "be like Mike" (basketball star Michael Jordan) if they chose to buy a brand of sugary colored water (Gatorade) or, to cite another popular commercial trope, if a male drank a certain brand of beer he would be more attractive to the opposite sex. The power of consumerism has been its ability to make multiple identities possible through consumption, even those associated with anti-consumerism, such as environmentalism. One could, for instance, choose to communicate "I am an environmentalist" not just by

${ }^{2}$ On the long-term, global rise of consumerism, see the edited volumes and work of Frank Trentmann, particularly his wide-ranging study (2017) Empire of Things: How We Became a World of Consumers, from the Fifteenth Century to the Twenty-First. London: Penguin Books.

${ }^{3}$ This interpretation of the role of modern advertising comes from Sut Jhally. 2016. Codes of Advertising: Fetishism and the Political Economy of Meaning in the Consumer Society. New York: St. Martin's Press. 
hugging a tree but by driving a hybrid Prius rather than a gas-guzzling Hummer.

Critics contend that consumerism creates a narcissistic culture. ${ }^{4}$ Rather than personal empowerment, consumerism undermines self-confidence and self-worth by teaching people to focus on a never-ending list of personal faults that, once recognized, must be corrected through informed consumption. ${ }^{5}$ Expressing values becomes an exercise not done through social deeds aimed at improving the collective good but rather by fulfilling individual needs and desires through commodified things and experiences. Everything shifts toward values mediated by consumerism across all areas of life, including areas seemingly antithetical to consumerism. As the CEO of one religiously affiliated financial company observed, people are taught to interact with their churches not as members of a community but rather as "consumers." They then begin to fix the problems of their church not as co-members of a community but rather by finding a more suitable church, that is, by choosing a different product. ${ }^{6}$ The secular world of politics has seen similar transformations under consumerism. Rather than seeing politics through the lens of citizens who set the entire political agenda, residents of "democratic" countries have become consumers who select a political product. To add a third example of the ubiquity of consumerist values, college professors complain of the same: students see themselves as consumers who do the choosing rather than students to be educated.

While consumerism predates the industrial era that led to mass production, modern consumerism spread quickly starting in the late nineteenth century. ${ }^{7}$ Industrial production meant producers had to find new

\footnotetext{
${ }^{4}$ The classic expression of this interpretation comes from historian Christopher Lasch. 2018. Culture of Narcissism: American Life in an Age of Diminishing Expectations. New York: Warner Books.

${ }^{5}$ For a brief and accessible introduction to examples of sexist stereotypes used both to teach "faults" such as grey hair or skin blemishes and sell products for women to fix them, see http://www.dailymail.co.uk/femail/article-5463181/Vintage-ads-reveal-sexistcampaign-slogans.html. Accessed 8 August 2018.

${ }^{6}$ Brad Hewitt and James Moline. 2015. Your New Money Mindset: Create a Healthy Relationship with Money. iBook, no pagination. They write: "People show up less as worshipers or community members than as consumers. As soon as an engaging preacher leaves or a great musician moves on, the church down the road suddenly looks a lot better. That's a consumer mindset....".

${ }^{7}$ For an overview of the pre-modern history of consumerism, see John Brewer and Roy Porter, eds. 1994. Consumption and the World of Goods. New York: Routledge. On the
} 
ways to stimulate desire. State power in the form of imperial expansion help spread consumerism abroad by "opening" new markets. Imperialist powers taught inhabitants their countries were comparatively "backwards" and needed to "catch up." Overt military force as well as the subtler means associated with the introduction of mass-produced products taught this lesson of backwardness. Once they gained market access, foreign companies convinced populations to have new material needs and wants. Billions of dollars of advertising, for instance, flowed into new forms of mass media such as newspapers and radio. ${ }^{8}$ By the early twentieth century, advertising had shifted from focusing on the specific uses of a product (e.g., buy a bicycle to get to work) to the identities one could create and communicate to others through possessing things (e.g., possess a bicycle to communicate class, masculinity, and other attributes). ${ }^{9}$

The People's Republic of China (PRC) provides a good place to explore the history of the universal phenomenon of consumerism. The tension between consumerism and non-materialistic values is highly visible in contemporary China because the country started to industrialize relatively late and because since 1949, after the Communist Revolution, it claimed to be industrializing without "bourgeois" consumerism, as a country that was "building socialism." The rush to "catch up" with the dominant global powers led to both positive and negative outcomes. The positive side is well known: a record of leading hundreds of millions out of extreme poverty. But the explosive growth in the PRC also included a consumerism that created or exacerbated innumerable urgent crises: childhood obesity, extreme markets for body parts and endangered species, acid rain falling on $1 / 3$ of the country, and many other human

Chinese antecedents, see Craig Clunas. 1991. Superfluous Things: Material Culture and Social Status in Early Modern China. Champaign: University of Illinois Press.

${ }^{8}$ For general coverage of the spread of advertising, see Mark Tungate. 2013. Adland: A Global History of Advertising, Ed. 2. Philadelphia: Kogan Page. For a good example of how new technologies spread awareness and desire for products via advertising, see Steve Craig. 2009. Out of the Dark: A History of Radio and Rural America. Tuscaloosa: University of Alabama Press.

${ }^{9}$ For an account of one global company in China and the marketing techniques it introduced to cultivate desires, see Sherman Cochran. 1980. Big Business in China: SinoForeign Rivalry in the Cigarette Industry, 1890-1930. Cambridge: Harvard University Press. 
and environmental catastrophes. ${ }^{10}$ The PRC provides particularly striking evidence of how consumerism dominates the contemporary world.

The history of consumerism in the PRC also reveals consumerism as a formidable foe embedded in all industrial societies. Since the rise of modern consumerism in the late nineteenth century, nations and individuals have learned to compete through consumption. The compulsion to compete through consumption was part of the global political economy in both "socialist" and "capitalist" countries during the Cold War. Consumerism developed even during the time when Chairman Mao Zedong was the preeminent leader, from the establishment of the PRC in 1949 to his death in 1976 (hereafter, the Mao era). This chapter discusses the compulsion to adopt the values of consumerism and compete through consumption, including at the height of the Mao era, and the Chinese Communist Party's (CCP) efforts to create an alternative "socialist" culture. The reinterpretation of the Mao era as promoting rather than quelling consumerism contextualizes the last part of the chapter, an examination of how this state-led consumerism of the Mao era continued into the early 1980s, when the CCP shifted dramatically from attempting to suppress consumerism to promoting both private enterprise and "bourgeois" consumerism.

\section{The Compulsion to Consume}

The recent history of PRC reveals the power of consumerism to displace other values. After the Communist Revolution of 1949, CCP leaders claimed they were building a radical "New China", with a "New Society", which fundamentally broke with both the pre-1949 "Old Society" as well as global capitalism. ${ }^{11}$ The critical turning point was the victory of the CCP and the "liberation" of China in 1949. In official histories, the

${ }^{10}$ I cover the negative consequences of the post-1978 promotion of consumerism in Karl Gerth. 2013. As China Goes, So Goes the World: How Chinese Consumers Are Transforming Everything, Chapter 7. New York: Farrar, Straus and Giroux. Many other books detail individual crises. On the obesity epidemic that has accompanied expanding consumerism, see Paul French and Matthew Crabbe. 2010. Fat China: How Expanding Waistlines Are Changing a Nation. London: Anthem Press.

${ }^{11}$ Michael Schoenhals. 1992. Doing Things with Words in Chinese Politics: Five Studies. Berkeley: Institute of East Asian Studies, Center for Chinese Studies, University of California. 
Communist Revolutionaries "liberated" China from the domestic ("semifeudal") and international capitalist ("semi-colonial") forces that enslaved the country and kept China poor and weak. Consequently, the Socialist Revolution was not merely a violent power struggle between two contending political parties - the Nationalist Party (KMT) under Chiang Kaishek versus the CCP led by Mao Zedong. According to the revolutionaries themselves, the civil war was a conflict over two fundamentally different visions of how to transform China into a wealthy and powerful country: capitalism vs. socialism.

The idea that the PRC was building an anti-capitalist, anti-consumerist nation served both sides in the Cold War and still predominates in popular interpretations. Even academics and popular histories outside of the PRC conventionally echo the CCP language by framing the history around the embrace of socialism in 1949 and its transformation in 1978. ${ }^{12}$ Global populations learned to see China through the frame of socialism. Adversaries of the PRC and CCP abroad, led by the United States, reinforced the idea that 1949 was a revolutionary socialist (or "communist") break with the capitalist countries. Throughout the Cold War (and in some cases down to the present), politicians, scholars, and the mass media-in China and its adversaries-cast their differences as differences between antithetical world orders. ${ }^{13}$ "Communism" versus "capitalism" became the terms both sides used not only to describe their opposition but also themselves. Depicting the tensions between Cold War adversaries as battles between two completely different ways of life was as crucial for domestic cohesion and discipline as for the battle for the hearts and minds of the opposing populations. ${ }^{14}$

${ }^{12}$ Scholarly accounts almost universally emphasize these breaks. The same applies to college courses, which mostly begin in 1949 or end in 1978. There are a growing number of exceptions that question CCP formulations. See, for instance, Frederick Teiwes and Warren Sun. 2015. Paradoxes of Post-Mao Rural Reform: Initial Steps Toward a New Chinese Countryside, 1976-1981. New York: Routledge.

${ }^{13}$ For an illustration of these contrasting ways of life in the popular (US) imagination during the height of the Cold War, see the Armed Forces Information Film "Freedom and You," rereleased in 1962 as "Red Nightmare," which presents as an educational film of what American life in a small town would have been like under "communism." https:// www.youtube.com/watch?v=cgR4apcz_Ew. Accessed 21 July 2018.

${ }^{14}$ This theme is discussed in Oscar Sanchez-Sibony. 2014. Red Globalization: The Political Economy of the Soviet Cold War from Stalin to Khrushchev. Cambridge: Cambridge University Press, 9 n. 6 and throughout. 
Yet, even after the CCP came to power in 1949, decades of mass campaigns and state rhetoric vilifying "bourgeois" consumer desire as a threat to "socialist construction" not only failed to destroy consumerism but even helped spread it into new classes and places. Consumerism spread because all industrializing countries competed with each other and within themselves over both big and everyday technologies. Competition over the more capital-intensive "big technologies" was more conspicuous in the form of railroads, telegraphs, mining, large-scale irrigation, electrification, and, most importantly, national "defense" technology. Such competition between nations easily appears as vanity. In the twentieth century, big technologies became icons of national wealth and power. ${ }^{15}$ Having better technology (such as an atom bomb) became a measure of national success that conferred political legitimacy. Nations competed over big technologies as conspicuous measures of their success overcoming earlier "backwardness."

National wealth-and political power-depended on successful competition. Without big technologies the CCP could not compete against the British, Japanese, Americans, and smaller imperialist powers for both the latest and most necessary forms of national security and economic infrastructure. An atom bomb, which the PRC first exploded in 1964, became the clearest manifestation of competition over big technologies. ${ }^{16}$ Without an atom bomb and other big technologies, particularly weapons, the PRC would have faced even greater threats of military invasion. In effect, competition was compulsory. Likewise, without secure borders, imperialist powers would have continued to dominate the economy, as they had in the first half of the twentieth century. Big technologies were critical to specific forms of economic competition. They increased productivity and lowered transaction costs. New railroads, for instance, enabled PRC economic planners to move northwest coal to southeast factories, thereby making the latter more productive. Before and after the establishment of the PRC in 1949, Chinese leaders knew the country had to

15 The best-known book on this topic is: Michael Adas. 2015. Machines as the Measure of Men Science, Technology, and Ideologies of Western Dominance. Ithaca: Cornell University Press. On competition over big technology in China specifically, see Anne Reinhardt. 2018. Navigating Semi-Colonialism: Shipping, Sovereignty, and Nation-Building in China, 1860-1937. Cambridge: Harvard University Press.

${ }^{16}$ Joseph Cirincione. 2007. Bomb Scare: The History and Future of Nuclear Weapons. New York: Columbia University Press, 51. 
compete to create or acquire big technologies. Without those continual improvements, the PRC could not compete for markets and earn the capital needed for big technologies.

While military and economic rivals created a national compulsion to compete in big technologies, there was simultaneous competition over new "everyday technologies" that helped drive consumerism. These were less conspicuous and capital-intensive than big technologies, and included sewing machines, bicycles, timepieces, typewriters, radios, gramophones, cameras, rice mills, and a host of others. ${ }^{17}$ Mass-produced everyday technologies transformed all aspects of day-to-day life. In the process, they also helped introduce the idea of backwardness and, thereby, the compulsion to "catch up." Even without modern advertising designed to teach people about their inadequacies, the spread of these everyday technologies popularized a notion of individual backwardness that could only be overcome with the acquisition and mastery of mass-produced products, things one had to buy. The consequences of failing to acquire and master everyday technologies powerfully shaped identities and thereby increased the desire to possess things. The pride of knowing how to ride a bicycle or operate a sewing machine, particularly when few did, also provided a person or family with material advantages. Likewise, competition over knowledge and possession of everyday technologies recreated many of the inequalities the CCP claimed to correct: urban over rural; mental over manual; coastal over interior (and, later, male over female). Conversely, the lack of knowledge - much less possession — of everyday technologies generated shame that one had not mastered everyday technologies.

The national and individual compulsion to compete by possessing big and everyday technologies meant the stakes related to consumerism were - and remain-great. Since the start of industrialization in China in the late nineteenth century, high stakes have continually justified a much greater state role in managing consumption and consumerism, a realm of activity often thought to be about personal choice. In the realm of politics, "catching up" and overcoming relative backwardness has been a fight that helps justify CCP monopoly control over the state and, indeed, the necessity of a "socialist" country having a strong state. As with other countries struggling to overcome relative backwardness, the CCP has long

${ }^{17}$ The expression "everyday technologies" comes from David Arnold. 2013. Everyday Technology: Machines and the Making of India's Modernity. Chicago: The University of Chicago Press. 
considered as too risky the idea of letting the markets- free of state intervention-decide national and individual priorities. What if the market catered to the needs of the very wealthiest for, say, bigger yachts rather than national needs for domestically produced technology such as, figuratively speaking, an atom bomb? And, more recently, what if domestic consumers preferred a foreign-controlled social media website to a Chinese one?

While the state has been critical to shaping consumerism, the general population helped spread consumerism by turning what had been unimaginable luxuries in the decades before 1949 into everyday products. The three most highly sought-after products of the Mao era demonstrate the role of mass production in spreading consumer values in a "socialist" country. Beyond the basic necessities, people in cities, towns, and villages around the country most commonly desired what became known as the Three Big-Ticket Items ( san da jian, hereafter, the Big Three). The exact Three varied by time and place but most often included a wristwatch, a bicycle, and a sewing machine. ${ }^{18}$ Throughout the 1940s, all three were hard to acquire, usually manufactured by foreign-owned companies or imported, and only found in the homes of the better-off. As the domestic industry recovered from decades of war in the 1950s, for most people, even having any one of the three was an accomplishment. However, the trend over the course of the Mao era led to near-universal awareness, desire, or possession of the Big Three. CCP policies spread consumerism by making the Big Three increasingly available to people in cities, towns, and even parts of the countryside. By the end of the era, they had gone from being comparative luxuries to being so commonplace that the original Big Three were no longer considered extravagances. Consumerism continually expanded-alongside production-in the form of new desires. The Big Three of the 1980s became some combination of TVs, washing machines, electric fans, and portable cassette players. By the 1990s, people desired stereos, mobile phones, microwave ovens, refrigerators, and personal computers. And now the upwardly mobile dream of cars, apartments, leisure travel, and other more expensive things. And, of course,

18 Although those starting a new household often considered a sewing machine one of the essential Big Three items, some young people preferred a radio or a camera. Wool clothing was also sometimes described as one of the Big Three, especially as part of a betrothal gift. 
the growing consumption of these consumer goods have become a crucial aspect not only of consumerism but also new rounds of economic growth in China. ${ }^{19}$

Consumerism-the desire to communicate identity through the consumption or use of things-spread at the level of ordinary life thanks to the immediate practical uses as well as the broader social value of the Big Three. Demand grew because industrialization made the Big Three increasingly indispensable as labor-saving technologies, modes of transportation, and labor multipliers (i.e., the same amount of labor produced more products). ${ }^{20}$ The desire for watches, for instance, reflected the new discipline over time, particularly those working on highly time-dependent "factory time" rather than by the sunlight in agricultural fields. Individual ownership by factory workers, for instance, meant they could not only show up on time for work but also resist manipulation of a central clock by their employers. ${ }^{21}$ Likewise, bicycles symbolized the need for greater mobility, for instance, to get to a job or to transport agricultural products to markets. And sewing machines created opportunities to increase female productivity through sideline work. The broader social uses of the Big Three multiplied so fast and became so important for everyday life that acquisition and mastery became, in effect, increasingly compulsory. Everyday life pushed people to desire the Big Three for social uses such as bribes to officials, ways to store value after a good harvest, and even as enticements offered by parents to get their children to study harder for school entrance exams. Even toothbrushes and toothpaste taught new ideas of the body and hygiene: teeth required regular brushing-as well as class and urbanity - and those who did not know to brush their teeth,

${ }^{19}$ On the state role in promoting cars, including electric vehicles, see Karl Gerth. 2015. "Driven to Change: The Chinese State-Led Development of a Car Culture and Economy," in Atle Middledun and Nina Witoszek (eds.), Energy Transport in Green Transition: Perspectives on Ecomodernity. New York: Routledge.

${ }^{20}$ On farmers hoarding the Big Three, such as one that bought ten bicycles, see Ren Yuanhang, "Shucai diqi bufen nongmin zizhang langfei xianxiang" (The Phenomenon of Vegetable Farmers Overspending), Hangzhou Daily, 25 July 1957; and "Qian yao yong zai daokou shang" (Money Ought to Be Spent on the Blade), Hangzhou Daily, 22 August 1957. On bribing children with watches, see Guang Jun, "Hang Liu Zhong zhaokai jiazhang hui" (A Parents' Meeting in Hangzhou No. 6 Middle School), Hangzhou Daily, 27 March 1957.

${ }^{21}$ E. P. Thompson. 1967. “Time, Work-Discipline, and Industrial Capitalism.” Past \& Present 38: 56-97. 
much less actually brush them, were "backward." 22 Products enabled and created the social need to communicate something as taken-for-granted as "I know how to ride a bicycle" or "my family is prosperous and connected enough to acquire a sewing machine." Products and their social environments overrode "socialist" attempts to suppress consumer desire.

Perhaps the most important function of the Big Three came with every family wanting to marry off its young men to suitable women. Despite endless admonitions to keep weddings simple, throughout the Mao era and since, a bride's family expected even modestly well-off young men's families to provide at least one and ideally all Big Three at the time of betrothal. Failure to do so suggested that the groom was an undesirable match. This expectation-embodied in the concepts of "perfect match based on comparable standing" and "face" transcended the Socialist Revolution of 1949 and was so deep-seated in cities and villages that in some cases, the groom's family would borrow money to obtain the necessary items and pay off the debt after the marriage. The continued desire for specific products to assess and reinforce social differences underscores the impossibility of creating a "socialist" culture with values built entirely around self-sacrifice and austere "proletarian" uniformity egalitarianism. ${ }^{23}$

And competition was never-ending. In addition to the inflation of desires noted above, hierarchies based around brands further expanded consumerism. As industrialization and consumerism developed, not everyone was satisfied once they possessed one item or even a generic item in that category. One might want not just any wristwatch but only a Shanghai brand wristwatch or even the latest model, lest they feel ashamed by a dated or inferior model. In the eyes of some upwardly mobile Lower Yangzi delta residents, for instance, at one point, the height

${ }^{22}$ For an accessible overview of bodily practices such as brushing one's teeth that emerge in the late nineteenth century, see Ruth Goodman. 2015. How to Be a Victorian: A Dawn-to-Dusk Guide to Victorian Life. London: Viking. Henrietta Harrison covers some these topics for China in (2011) China: Inventing the Nation. New York: Oxford University Press.

${ }^{23}$ On the frustrations of rural cadres attempting to eradicate betrothal gifts in the first decade of the PRC, see Neil Jeffrey Diamant. 2000. Revolutionizing the Family: Politics, Love, and Divorce in Urban and Rural China, 1949-1968. Berkeley: University of California Press. 
of fashion was for a young person to ride a Forever bicycle, wear a Shanghai brand watch, and listen to a Red Lantern radio. ${ }^{24}$ "Socialist" countries such as China also witnessed the development of consumerism to include communication through branded products.

Of course, the proliferation of products did not spread uniformly. Consequently, the centrality of the values introduced by consumerism varied by place and time. A factory manager in Shanghai-where there were at least ninety well-known product brands by the end of the Mao erawould have had different experiences than a rural farmer. This factory manager, for instance, would have had greater knowledge of and desire for an Enicar imported Swiss watch than, say, a farmer in rural Guangxi province. ${ }^{25}$ While the manager would have had a greater need to participate directly in consumerism, many millions did not engage in much consumption, much less "consumerism." It is easy to imagine villages throughout China that during this period had little to do with communicating identity through buying things. The country was, after all, starting from a position of extreme poverty. Few rural residents-and not that many urban ones-dreamed of Enicar watches. Nevertheless, possession-or lack thereof-alone introduced new social cleavages in a country claiming to be building a more egalitarian country.

New forms of social differentiation based on knowledge about and desire for products spread faster and further than their acquisition. Countless tens of millions of urban and rural households across China-and in increasing numbers-began to learn about, desire, and even feel compelled to want and use everyday technologies. Even a very poor person with little chance of acquiring a bicycle or sewing machine might have seen the Big Three on street advertisements, witnessed them in a statemade movie projected by a traveling film team visiting their isolated village, been told they were mandatory to secure a bride, or encountered them in countless other ways. Awareness and desire predated possession.

${ }^{24}$ Huang Ji Zahuo Pu (blog name), "Zhongguo shoubiao wangshi” (The History of Chinese Watches), 20 June 2009. http://blog.sina.com.cn/s/blog_609daf0f0100eeft. html. Consulted 8 July 2017.

${ }^{25}$ Zhu Zhanliang. 1981. "Shanghai qinggongye mingpai chanpin chutan" (A Brief Analysis of Famous Brands Produced by Shanghai Light Industry). Shanghai jingji yanjiu 9(9): 7-11. 


\section{The Limits of State Consumerism}

Attempts by industrializing countries such as the PRC to define alternative values to consumerism such as socialist egalitarianism failed. Consumerism was more powerful than state efforts to limit or control it. Still, the CCP tried to manage consumerism not only because it posed a threat to its stated "socialist" values but also because consumer desire threatened the CCP's economic development strategy. Since 1949, the CCP has followed the example of other "late-comer" industrializing countries and attempted to accelerate industrialization by managing both the production side and the consumption side of the economy. In the view of the CCP, the need to industrialize and "catch up" as quickly as possible meant individual consumer choices were too important to national wealth and power to be left in the hands of impressionable, uneducated, or even unpatriotic individual "consumers."

While the CCP's role in organizing mass production is well-known, less known is its related role in managing demand. In this chapter, the term "state consumerism" represents the wide-ranging efforts within the PRC to eliminate, discredit, or at the very least marginalize what the CCP depicted as a chief threat to its control over how to spend, or allocate, its resources. The CCP attacked as "bourgeois consumerism" many of those challenges to state control over allocations, particularly those allocations that reinforced and communicated "capitalist" values of inequality, individualism, and exploitation through the desire for and acquisition of products and services. By contrast, state consumerism involved efforts led by the CCP to suppress or channel consumer desire, including by promoting a distinctive "socialist" consumerism and condemnation of "bourgeois" and "feudal" consumerism. In the Mao era, state consumerist policies to enforce these values included eliminating imports of "bourgeois" goods such as British Raleigh bicycles, Japanese Seiko watches, and American Singer sewing machines and limiting the amount and placement of advertising that might otherwise stoke undesirable consumer desire. ${ }^{26}$ The CCP also used its monopoly control over the mass media to equate an ethos of "hard-work and frugal living" (jianku pusu) with "socialism." Put more concretely, unbridled desire for, say, imported

${ }^{26}$ Edward J. M. Rhoads. 2012. "Cycles of Cathay: A History of the Bicycle in China." Transfers 2(2) (Summer), 95-120. 
watches-whether fulfilled at a state-run store or on the black marketmeant less capital for the state to allocate on national priorities such as the figurative atom bomb. Similarly, too much desire even for China-made watches created pressure of the state to allocate more scarce resources into consumer goods rather than producer goods.

The CCP goals of controlling production and consumption permeated Chinese society. Manifestations of a state-controlled economy "commanded" to be productive appeared everywhere, from Five-Year Plans to backyard steel furnaces to the mass mobilization of millions to turn barren land into cultivatable land or build bridges and tunnels. This preoccupation with developing the forces of production-capital accumulation-also permeated all aspects of everyday life and undoubtedly made it easier to overlook the spread of consumerism. Movies and literature lionized model workers such as Hao Jianxiu, a textile worker who invented methods to improve productivity and reduce waste; model farmers such as Wang Guofan, who figured out ways to increase harvests; and model soldiers such as Lei Feng, whose diary recorded his tireless efforts to serve the nation and do so voluntarily, without remuneration. ${ }^{27}$ Alongside "frugality," the CCP wanted people in the "people's republic" to work for free.

State consumerism was contentious. States often sought to impose limits on individual choice, a central pillar of consumerism, in the name of a higher ideology emphasizing collective goals such as "socialism" or "nationalism." Again, such attempts were not unique to China or even "socialist" countries and spread across the globe through national mass campaigns urging "patriots" to abstain from imports and buy products now cast as "domestic," "home," "native" or "national" products. ${ }^{28}$ In China,

${ }^{27}$ Lily Xiao Hong Lee, ed. 1998. Biographical Dictionary of Chinese Women. Armonk: M. E. Sharpe, 198-200; Jack Grey. 1973. Mao Tse-tung. Cambridge: Lutterworth Press, 46-47; and Miin-ling Yu. 2010. “Labor Is Glorious': Model Laborers in the People's Republic of China," in Thomas P. Bernstein and Hua-Yu Li (eds.), China Learns from the Soviet Union, 1949-Present. Lanham: Lexington Books.

${ }^{28}$ Because all industrializing states attempted to manage consumption, the secondary literature is vast. The swadeshi ("belonging to one's own country") and non-cooperation movements in India (1904-1908, 1920-1922) are the best-known and best-studied examples of such an application of nationality to products. Historians of late-colonial America have also emphasized the early links between consumerism and nationalism. For example, see Arthur M. Schlesinger. 1957 [1918]. The Colonial Merchants and the American Revolution, 1763-1776. New York: Frederick Ungar; and Timothy H. Breen. 2010. American Insurgents, American Patriots: The Revolution of the People. New York: Hill and Wang. 
before 1949, popular and state demands that individuals prioritize "national interests" over market prices, personal preferences, or other considerations were a tough sell. This is hardly surprising. Individuals often ignored or were ignorant of such demands. There was little the state, manufacturers of "Chinese products," or enthusiastic supporters of this form of nationalism could do to enforce a "patriotic" interpretation of consumer culture by ensuring Chinese people bought "Chinese products." 29

However, after 1949, the CCP finally had the power to impose the more autarkic economic vision developed in earlier decades, to add much more "state" to state consumerism. Rather than simply hoping popular campaigns might determine "patriotic" preferences, the CCP could now also impose nationalistic consumption with the same macroeconomic tools used in various market capitalist economies-tariffs on trade, exchange controls on hard currency, and outright bans on imports. Despite the official hostility toward things such as American nylon stockings or Hollywood films, and the difficulty of finding them, consumers actually still favored such imports over domestic goods and sought them out in the name of comfort, fashion, or other personal reasons. But consumers in late-industrializing countries such as China often preferred less expensive, higher-quality, heavily advertised imports, a consumer preference directly at odds with state goals to exercise more control over capital allocations and develop domestic industry.

Ultimately, individual consumerist desires generated in industrial society proved impossible to dictate. Attempts to replace "bourgeois" consumerism with state control were more aspirational than actual. The CCP's inability to control demand is predictable. After 1949, workers took the victorious CCP at its word that the Revolution inaugurated "the dictatorship of the proletariat." Contestations arose between the CCP, which wanted to allocate the surplus for collective "national needs," and workers and farmers, who usually had their own priorities. Workers and

Such "Buy American" campaigns are so numerous in American history that there is a survey of such attempts across the entire history of the US. See Dana Frank. 1999. Buy American: The Untold Story of Economic Nationalism. Boston: Beacon Press; and Lawrence B. Glickman. 2009. Buying Power: A History of Consumer Activism in America. Chicago: The University of Chicago Press.

${ }^{29}$ On China's attempts to link consumption and nationalism, see Karl Gerth. 2003. China Made: Consumer Culture and the Creation of the Nation. Cambridge: Harvard University Press. 
farmers fought for greater control, both directly by demanding higher pay and indirectly by pilfering the fruits of their labor. Farmers wanted to keep more of the harvest; workers wanted higher pay to buy more food, better housing, and various consumer goods. ${ }^{30}$ Thus, immediate crackdowns on labor strikes and institutionalization of long-term forms of control such as state-run labor unions were actually attempts to suppress competing demands over the surplus and its allocation into more consumption.

Even CCP leaders remained ambivalent about consumerism. The consumerism of the pre-1949 era was rarely completely vilified or discredited. In China and throughout the Communist Bloc, earlier forms of consumerism persisted in ways such as branded products and the identities associated with them, often despite explicit state attempts to end or limit them and, surprisingly, sometimes with state support. Recent research on Eastern Europe and the Soviet Union has uncovered consumerism thriving behind the Cold War propaganda that has often obscured such aspects of everyday life in Socialist economies. ${ }^{31}$ In line with such scholarship, an examination of not only the persistence of but also the further spread of consumerism in the PRC challenges the still pervasive assumption that the country was a realm of pure asceticism, without room for any consumer desire. Indeed, this assumption of "socialist asceticism" has led scholars to write off black market and other "capitalist" activity as unexpected and exceptional. $^{32}$

Mao Zedong and many Communist leaders were often openly hostile toward the consumerism associated with urban, "bourgeois" lifestyles.

${ }^{30}$ Most recent studies on urban and agricultural work now emphasize contestation between workers and the state. See, for instance, Elizabeth Perry and Li Xun. 1997. Proletarian Power: Shanghai in the Cultural Revolution. Boulder: Westview Press.

${ }^{31}$ There is a burgeoning literature on the tensions created by consumerism within "socialist" countries, particularly in the German Democratic Republic. Helpful studies include the relevant chapters on East German advertising in Pamela E. Swett, S. Jonathan Wiesen, and Jonathan R. Zatlin, eds. 2007. Selling Modernity: Advertising in Twentieth-Century Germany. Durham: Duke University Press, especially the chapters by Anne Kaminsky and Greg Castillo. For an overview on the role of consumer politics in the (de-)legitimization of Communist Party rule in Eastern European states, especially as these states failed to keep up with the market capitalist Joneses in Western Europe, see Mark Pittaway. 2004. Eastern Europe, 1939-2000. London: Hodder Arnold.

32 This emphasis on the asceticism of the Mao era is common in popular accounts. See for instance, Frank Dikötter. 2017. The Cultural Revolution: A People's History, 19621976. New York: Bloomsbury Press. 
But from its first decades forward, the People's Republic reshaped consumerism in Chinese life, especially in charged political times when even more common commodities were labeled "bourgeois"-but never eliminated it. China continued to mass-produce branded goods, and commodities remained objects of everyday discussion as well as markers of personal and collective identities. It was relatively easy for the state to suppress supply and limit economic incentives (such as higher pay) in state-controlled industry, commerce, and agriculture but much harder for it to control desires. The state could (and did) elect not to manufacture enough bicycles, sewing machines, wristwatches and other consumer goods to meet desire. But it could not prevent people from learning about and desiring these things. And unfulfilled desire had consequences, including the inability of the state to control the economy. By the late 1970s, the CCP decided it needed to harness market capitalism and "bourgeois" consumerism for its own political and economic ends. Leaders such as Deng Xiaoping decided that the PRC could industrialize faster by stimulating markets and consumerism than by suppressing them.

\section{Official Embrace of Markets and Materialism}

Even after the end of the Mao era and the official sanctioning of markets and consumerism starting in the late 1970s, the state continued to play a critical role in spreading consumerism. Consumerism did not develop after the Mao era as a natural phenomenon that occurs anytime a state withdraws from interfering in the economy. Rather the CCP implemented specific policies that shifted the organization of production (work) and consumption (leisure) in ways that promoted consumerism. Above all, private enterprise led to more consumerism. And vice versa: more consumerism led tens of millions to seek non-state opportunities to make money to buy the things they needed for immediate uses as well as broader social uses.

In 1978, the CCP led by Deng Xiaoping officially sanctioned a major transformation of society as well as the PRC's relations with market capitalist countries, known as the "market reforms and opening" or simply "the reform era." 33 Leaders once again permitted small private plots

${ }^{33}$ Many works discuss the economic dimension of these policies, including Joseph Fewsmith. 1994. Dilemmas of Reform in China: Political Conflict and Economic Debate. 
for agricultural production and small-scale private enterprises. ${ }^{34}$ Millions of farmers began to have much more disposable income to buy the Three Bigs and fulfill new desires. Likewise, millions of "self-employed, household-run businesses," known as getihu, popped up following the policy changes at the top. Entrepreneurs established everything from dumpling stalls to interprovincial agricultural produce transport. Like their counterparts in farming, getihu suddenly had disposable income. Mom-and-pop shop proprietors changed China in their capacity as highly touted leading consumers in the mass media and popular imagination. Getihu became the figurative Joneses that other Chinese wanted to catch up with. Although the vast majority of getihu remained poor, their desires, and the unintended consequences of their struggles to fulfill those desires, transformed China in the 1980s.

Beginning in the 1970s, millions of new getibu became a primary force spreading consumerism. ${ }^{35}$ Statistics confirm the spread. In 1978, there were only 150,000 private businesses; a decade later, there were more than 14 million getibu. ${ }^{36}$ These numbers grew so fast in part because legalization of getihu effectively recognized - and attempted to regulateprivate economic activity that was already occurring. ${ }^{37}$ In contrast to the Mao era rhetoric of "socialist equality," in which displays of wealth were at times deemed crimes against the state or, at the very least, an indication of "thought problems," this accelerating privatization of the economy symbolized by the spread of getibu immediately produced new classes of

Armonk: M. E. Sharpe; Barry Naughton. 1995. Growing Out of the Plan: Chinese Economic Reform, 1978-1993. Cambridge: Cambridge University Press; and Carl Riskin. 1987. China's Political Economy: The Quest for Development Since 1949. Oxford: Oxford University Press.

${ }^{34}$ On local restoration of private plots without state authorization, see Kate Xiao Zhou. 1996. How the Farmers Changed China: Power of the People. Boulder: Westview Press.

${ }^{35}$ Susan McEwen. 1994. "New Kids on the Block." China Business Review 21(3) (MayJune): 35-39. On the consumption side of getibu activity, the sociologist Thomas Gold has written several articles on getihu based on personal observation. See, for instance, Thomas B. Gold. (1991). "Urban Private Business and China's Reforms," in Richard Baum (ed.), Reform and Reaction in Post-Mao China: The Road to Tiananmen. New York: Routledge, 84-103.

${ }^{36}$ Susan Young. 1995. Private Business and Economic Reform in China. New York: Routledge, 6.

37 Ole Bruun. 1991. Business and Bureaucracy in a Chinese City: An Ethnography of Private Business Households in Contemporary China. Berkeley: Institute of East Asian Studies, 48 . 
relatively prosperous Chinese who demanded Coke, Pierre Cardin shirts and countless other new and foreign consumer goods. ${ }^{38}$ Of 1490 getibu households in a single district of Tianjin by 1984, for example, 946 had acquired televisions, 433 cassette recorders, 90 refrigerators, and 48 motorcycles. ${ }^{39}$

Getihu were not alone in their consumerism. Over the first two decades of the "reform era," CCP policies, as the state mass media popularized, that "allowed for some to get rich first" and have higher incomes created different classes of newly prosperous and wealthy consumers. ${ }^{40}$ After rural workers, the first group to appear was the small-scale household entrepreneur (the getibu). As many of the 17 million young people "sent down to the countryside" before and during the Cultural Revolution decade (1966-1976) returned to Chinese cities seeking work, the Chinese government officially recognized that massive urban unemployment had to be addressed, but it was not prepared to allocate massive state resources to solve the problem. In February 1979, the Central Committee of the CCP approved a report by the State Administration for Industry and Commerce that advised the central government to allow unemployed people with urban "household registrations" to start their own private businesses, but restricted such businesses to repair, services and handcrafts. Initially, as leaders felt ambivalent about abruptly reembracing private enterprise, getihu were forbidden to hire workers, a restriction that was quickly ignored and gradually changed as the range and size of private businesses expanded. ${ }^{41}$ Virtually every business surveyed

${ }^{38}$ See Andrew Walder. 2015. China Under Mao: A Revolution Derailed. Cambridge: Harvard University Press, 331. As he notes, China was the most inegalitarian socialist country in the 1970s, with a Gini coefficient of 0.33 .

${ }^{39}$ Marcia Yudkin. 1986. Making Good: Private Business in Socialist China. Beijing: Foreign Languages Press, 30.

${ }^{40}$ For an overview of the policies and their effects on income and consumption, see Karl Gerth. (2011). "Lifestyles of the Rich and Infamous: The Creation and Implication of China's New Aristocracy," in special issue of Comparative Sociology 10(4): 488-507; and Xiaowei Zeng. 2008. "Market Transition, Wealth and Status Claims," in David S. G. Goodman (ed.), The New Rich in China: Future Rulers, Present Lives. London: Routledge, 53-70. For the larger context, see Martin Hart-Landsberg and Paul Burkett. 2005. China and Socialism: Market Reforms and Class Struggle. New York: Monthly Review Press.

${ }^{41}$ Chen Guanren. 2005. “'Wenge' you Zhongguo shoujia siying fandian: Yuebin fandian" (Yuebin Restaurant, the First Privately Owned Restaurant in China After the 'Cultural Revolution'), initially published in Zhongwai shu zhai 3, 32-35, www.zwszzz. com/DCFB/bkview.asp?bkid=191395\&cid=630477; and Dorothy J. Solinger. 1984. 
in Chengdu in the late 1980s had employees that were not, as they were required to be, registered. Such "employees" seldom included workers hired off the streets but rather were neighbors, distant relatives, and former co-workers. By 1985, getihu numbered nearly 10 million. Roadside bicycle-repair shops, food stalls, and fruit vendors appeared everywhere. In the countryside, home to three-fourths of these new enterprises, individuals set up fishing ponds, restaurants, repair shops, and other small businesses. ${ }^{42}$ Moreover, as limits on the number of allowable employees expanded, so did the numbers employed in the private sector, reaching more than 18 million by $1988 .{ }^{43}$

In their quest for better lives, individuals did not always wait for state permission. Many private businesses opened without permission, sometimes with encouragement from local officials authorized to experiment by allowing limited getihu activities. ${ }^{44}$ Or, local officials simply looked the other way, recognizing there was little they could do or wanted to do. As Chen Shouzhu, then an officer working for the Wenzhou Industrial and Commercial Bureau recalled, officers routinely blew a whistle to alert peddlers gathered at an open market that they were going to check for paperwork, giving them time to flee the area without fine or arrest. Chen also recounted a case of a woman selling dried shrimp in a local market in Wenzhou. When the police came, she attempted to commit suicide by throwing herself into Nine Mountain Lake. Local cadres such as Chen took this as a sign of the desperation of the jobless workers operating private businesses. Later that year, Zhejiang province officially

"Commerce: The Petty Private Sector and the Three Lines on the Early 1980s," in Dorothy J. Solinger (ed.), Three Visions of Chinese Socialism. Boulder: Westview Press, 73-111.

42 Bruun, Business and Bureaucracy, 62.

${ }^{43} \mathrm{Wu}$ Nan (2011) summarizes the trends and statistics for the establishment of getibu in, "Gaige kaifang hou de xiahai jingshang yanjiu" (A Study of the Trends of Going into Business After the Start of the Reform and Opening Era) (M.A. thesis, Liaoning University).

${ }^{44}$ The role of local officials in implementing these policies ahead of state authorization is explored in many places, including Jonathan Unger. 2002. The Transformation of Rural China. Armonk, NY: M.E. Sharpe; Edward Friedman, Paul G. Pickowicz, and Mark Selden. 2005. Revolution, Resistance, and Reform in Village China. New Haven: Yale University Press; and Marc Blecher and Vivienne Shue. 1996. Tethered Deer: Government and Economy in a Chinese County. Stanford: Stanford University Press, 63-85. 
allowed Wenzhou to start a pilot getibu program and the area became a national leader in private enterprise. ${ }^{45}$

Early getihu proprietors often were reluctant to entangle their businesses with the state and obtain licenses, worrying that once licensed, official approval could be reversed and getihu activities cited as evidence that they were a "capitalist tail," a common insult leveled against anyone engaged in private commerce in previous decades. Consequently, the CCP worked hard to change the perception of getihu from reviled "tails of capitalism" to "national labor heroes." Ye Yongguo, for instance, started his business in 1982, when he was 22, by renting a stall in Huncheng East Road in Wenzhou, where he sold women's clothing. As with so many other getihu, he felt embarrassed to be a petty businessperson. When acquaintances approached his stall, he hid and had his mother work the stall until they left. Yet a year later, in 1983, he was named a "National Advanced Individual Worker" for his successful business. Newspapers and radios broadcast his story for over a month. By the end of 1983, there were over 80,000 getihu in Wenzhou alone. ${ }^{46}$

The CCP played a supportive role by using state-run media to celebrate countless other getihu. The case of the first authorized getihu in Hangzhou, a young woman who worked as a photographer at a famous tourist site, demonstrates the critical support given by the state and the ways private businesspeople influenced China in the early 1980s. The photographer's case also uncovers one of the many difficult transitions underlying the shift from the "socialist" to the "postsocialist" era. The state was involved in determining the shape and pace of these transitions. Hence, despite the rhetoric, this and millions of other getibu cases were not simply "David vs. Goliath" stories of hardworking getihu pitted against corrupt state-owned enterprise employees. Rather these cases also represent the state shifting sides to favor the non-state economy, a shift that encountered some popular and bureaucratic resistance. The spread of getibu, then, also tells the story of the erosion of "socialism," which had featured the near absence of private enterprise since the late 1950s,

${ }^{45}$ You Chengyong, Xiao Xinhua, and Wang Danrong, "Wenzhou getihu: shichang xianxingzhe-huayuan Zhongguo diyi dai getihu de neiduan lishi" (Wenzhou getihu: Market Pioneers-The History of China's First Generation of getibu). Wenzhou ribao, 7 July 2008.

${ }^{46}$ You Chengyong, Xiao Xinhua, and Wang Danrong, "Wenzhou getihu." 
and the creation of its replacement, first with getihu and later by stateconnected ("crony capitalism"), state-owned enterprises ("state capitalism"), and multinational corporations.

State sanctioning of getihu was a practical policy implemented to find work for the millions of youth waiting for state-provided work assignments and "sent-down youth" (also known as "educated youth" or by the Chinese term, zhiqing) returning to Chinese cities from the countryside. The most practical dimension of the policy: millions of such youth found work with little state assistance and without needing the state to underwrite their jobs. In such accounts, the state allowed private business; people seized the opportunity. But the state indirectly led people to become getihu by narrowing their options. This was the case for Hangzhou's first getibu. The state effectively limited Gan Jing's options by propagating social castes based on family backgrounds that made it more difficult for her to find a job within the state sector. ${ }^{47}$ Gan's father had been an architect in Indonesia in the 1950s and, along with his Indonesian-born ethnically Han Chinese wife, responded to the call to ethnic Chinese to help build New China. Shortly after moving to China, however, they were classified as "Rightists" and relocated to Manchuria to log forests. Toward the end of the Cultural Revolution decade, they returned to Zhejiang Province. Gan Jing, who was born in Dalian in 1960 while her father was working as a lumberjack, remained in China with her paternal grandparents. ${ }^{48}$ She was also hurt during the Cultural Revolution after neighbors mistook the sound of her grandmother using a sewing machine to mend clothing at night as a telegraph transmitting secret messages overseas. Her father was labeled a counter-revolutionary and locked up in a makeshift prison at Yuyao Longquan Mountain in Zhejiang province for 56 days. As a consequence of her family's political troubles, when it came time to go to university, she had to pick a less popular major, settling on the study of tourism at Zhejiang University. When she graduated in the summer of 1978, she could not find a state work unit willing to employ someone with her family background. So she went back to Dalian and lived with

${ }^{47}$ Wang Qiuhang. 2015. "Yihuang sanshi nian, fangfu jiu zai yanqian” (Everything Still Remembered Vividly After 30 Years). Lao Zhaopian 99: 73-83. Shandong: Shandong huabao chubanshe, Issue 99, 73-83.

${ }^{48}$ Wen Dao interview of Gan Jing, "Hangzhou diyiwei getihu" (The First getihu in Hangzhou). Hangzhou ribao, 16 March 2016. http://hzdaily.hangzhou.com.cn/hzrb/ html/2016-03/16/content_2217432.htm. Consulted 16 April 2017. 
relatives, where she apprenticed herself at a state photo studio for a year, returning to Hangzhou in early 1981 with her honed photography skills.

The state also indirectly encouraged Gan Jing and millions of other unemployed youth to consider becoming getihu by using state-controlled media to praise the new policies and provide successful role models. ${ }^{49}$ Gan herself first read such stories in local newspapers in the spring of 1981. And the state also directly intervened in her decision-making. Gan and other unemployed youth were reluctant to test the policy locally, fearing police harassment, social stigma, and, above all, removing themselves from the queue for state jobs and benefits at a time when few voluntarily abandoned the state sector. ${ }^{50}$ Although she knew about the getibu policy, it took visits to her house by officers of labor department and industrial and commercial department, who were encouraging such unemployed youth to apply to be getihu. Gan Jing started work easily enough, borrowing 200 yuan and bought a Seagull brand camera and, on November 13, 1981, obtained the first getihu license and badge in Hangzhou. Gan Jing recalled that because she was the first and because she was a woman, the cadres, who needed to recruit other getibu, looked after her, making her registration easy. Moreover, the Tax Bureau gave her a tax holiday for her first year, an important concession and signature way officials favored private - even foreign - over state enterprises throughout the postsocialist era. Others followed, including the second and third getibu in Hangzhou, also young female photographers. ${ }^{51}$

To be sure, the Chinese state played a critical role in the early days of creating openings for getibu and simultaneously undermining the economic and social place of employees at competing state-owned enterprises. In other words, the state not only passively "let" some get rich first, state representatives at all levels - from Deng down-actively implemented policies and, at times, intervened in local squabbles to ensure the success of actual getihu. State support of getihu was essential to their success.

49 There were, of course, countless other "Gan Jing's" lauded by the state. For a collection of similar success stories, see Wang Lingxu, ed. 1993. Ziyou guodu: gongshang getibu shenghuo jishi. Shanghai: Shanghai Academy of Social Sciences Press.

${ }^{50}$ See also the case of Zhang Huamei, the first getihu in Zhejiang Province, who had earned a fortune but was still ashamed of being a getihu.

${ }^{51}$ Wen Dao, "Hangzhou diyiwei getihu." 
Sanctioning getibu became a new way for the CCP to continue to shape and endorse consumerism. As over ten million "educated youth" (zhiqing) returned to Chinese cities from their rustication, joining the already swollen ranks of those waiting years for government-assigned jobs, allowing very small-scale private enterprise in the form of getihu was an inexpensive fix. In addition, getibu filled innumerable holes in the Chinese economy, particularly in basic services ranging from bicycle repairs to restaurants and food stalls. Moreover, a getihu from Shenyang claimed that his produce transport business preempted social problems associated with food price spikes. For instance, in 1987, the price for green peppers doubled in local markets. One enterprising getihu quickly sourced several tens of thousands of the vegetables from Guangdong and Guangxi provinces, on the other side of the country, which reduced the price below its pre-spike price. ${ }^{52}$

Getihu spread consumerism locally as symbols of the advantages of "market reforms" and the justification for further market policies such as the expansion of the private economy at the expense of the statecontrolled economy, whether in the privatization of state-owned enterprises in the cities or in the disbanding of agricultural communes in the countryside. While the vast majority of getibu did not get rich quickly (or at all), in the state-controlled mass media and the popular imagination, getihu became symbols of a surefire pathway to consumer plenty. This shift had political implications critical for understanding the transition to the post-Mao "reform era." Blame for individual economic problems such as unemployment or lack of ability to buy the Three Bigs-and responsibility for solving these problems - shifted onto an individual and his or her relationship to markets rather than to the state and its handling of the economy. The CCP endorsed a message that said, in effect, if you cannot find a job and therefore cannot afford the things you desire, use your own initiative and find your own source of income such as selling homemade dumplings on a street corner. That solution-self-reliance-had its complement in consumerism. Can't afford betrothal gifts? Or, unlike your neighbors, can't afford a color TV, a refrigerator, washing machine, or

${ }^{52}$ Liu Zhiqing, "Ziyou guodu—guanyu getihu jingji quan de baogao he sikao" (A Land of Freedom-A Report and Reflections on the getihu Economic Circles). Initially published in Yalujiang zazhi 9: 1988. Reprinted in Wang Lingxu, ed. 1993. Ziyou guodugongshang getihu shenghuo jishi (A Land of Freedom-A Record of the Business getibu Economy). Shanghai: Shanghai Academy of Social Sciences Press. 
even a tape recorder-the new must-have Big-Ticket items? Start a business and with your earnings, compensate for the traditionally and Mao-era low-status associated with commerce by buying high-status items in the form what the Big Three became in the 1980s: a combination of TVs, washing machines, electric fans, and portable cassette players.

It would be easy to describe the foregoing as the natural consequence of the shift from socialism to capitalism in the 1980s. Once upon a time, the state was responsible for everything; then in the 1980s, the market took command. But such a conclusion overlooks the critical role the state played in creating getibu and promoting the positive values associated with them and with the market during the transitions of the 1980s. This state role extended from the national top, particularly in the "reform and opening" policies, to their local implementation in the "smashing of the iron rice bowl" of employment in state-owned enterprises. Neither at the national level nor at the local level did the state "get out of the way" and allow markets to reappear spontaneously. Despite his famous mandate that China "let some to get wealthy first," Deng Xiaoping and the Chinese state did not simply step aside and "let" anyone become wealthy. State policies and their implementation smoothed the path for some to get wealthy first and, in fact, directly or indirectly pushed them to try. ${ }^{53}$

Consumerism was an underlying driver of change. The neighbors of getihu such as Gan Jing envied them not for political reasons-because they were the first to embrace policy changes-but rather for economic reasons. Getibu were the first who could afford nice things, the first to get rich. The perception: the lifestyles of state-owned enterprise employees, the "labor aristocracy" of the Mao era who had benefitted materially the most, had fallen behind getihu competitors. And the gap grew quickly and conspicuously. The Mao era state economy and "socialist" values were not only dismantled on orders from above but also unraveled bit-by-critical-bit from below. The "reform" policies were supported and spread, even in advance of official authorization, because people wanted the latest Big Three. And each new Three Big item begot the desire, even

${ }^{53}$ On the elite political debates over these policies, see Frederick Teiwes and Warren Sun. 2015. Paradoxes of Post-Mao Rural Reform: Initial Steps Toward a New Chinese Countryside, 1976-1981. New York: Routledge; and 2007. The End of the Maoist Era: Chinese Politics During the Twilight of the Cultural Revolution, 1972-1976. Armonk: M. E. Sharpe. 
a need, for a ten more, making any policy reversal increasingly difficult, if not impossible.

CCP policy constructed markets and thereby determined who got rich first, that is, who got to consume what, who could afford the latest Big Three. In the 1980s, the state's role in making some rich first was more subtle, leading scholars to interpret the 1980s as a hopeful decade of mom-and-pop-led entrepreneurial capitalism and freedom in consumerism. These scholars then contrasted the economic freedom of the 1980s with the 1990s, when revived state-owned enterprises (SOEs) became profit-oriented corporations much more directly linked to the state. ${ }^{54}$ The history of consumerism in the PRC teaches that there was no decade of state-free markets and consumerism.

CCP policies effectively promoted consumerism, even during the avowedly anti-consumerist Mao era. Consumerism, therefore, did not arise spontaneously as part of "human nature" with the collapse of the "socialist" experiment after the Mao era. Long before the "reform" era led by Deng Xiaoping, consumerism spread as part of industrialization. Advocates of non-consumerist values will find in this history of the ascendance of consumerism in China a formidable foe. As with other places, consumerism in China has found ways to commercialize everything, even Christmas, which in China was absorbed into one-long consumer shopping period stretching from Single's Day (November 11) through Christmas and up until Chinese New Year a month or so later. ${ }^{55}$ But they may also find opportunity: more consumerism also has witnessed more opposition to the values associated with consumerism in recent decades. There has been both an increase in consumerism and a backlash in the form of attempts to promote other values. The number of Christians, for instance, is skyrocketing. According to the Council on Foreign Relations, China may have the largest number of Christians by 2030, over 240 million believers. The number is growing so quickly that it is predicted to soon surpass the number of members in the CCP itself, some 90 million in

\footnotetext{
${ }^{54}$ Yasheng Huang. 2008. Capitalism with Chinese Characteristics. New York: Cambridge University Press. For a thorough critique, see Joel Andreas. 2010. "A Shanghai Model?" New Left Review 65 (October-November). Another influential study that downplays the role of the state in the economic transformation is Victor Nee and Sonja Opper. 2012. Capitalism from Below: Markets and Institutional Change in China. Cambridge: Harvard University Press.

55 Robert Foyle Hunwick, "Why Christmas Is Huge in China." The Atlantic, 24 December 2014.
} 
$2017 .{ }^{56}$ However, as consumerism is deeply imbedded in all industrialized societies, the ability of non-consumerist values to resist commodification - and defy being turned into consumerist expressions-remains an open question. Even non-consumerist values such as going to church or celebrating Christmas have tended to become part of consumerism. ${ }^{57}$

\section{BIBLIOGRAPHY}

Adas, Michael. Machines as the Measure of Men Science, Technology, and Ideologies of Western Dominance. Ithaca: Cornell University Press, 2015.

Albert, Eleanor. "Christianity in China." Council on Foreign Relations. https:// www.cfr.org/backgrounder/christianity-china, 2018. Accessed 15 August 2018.

Andreas, Joel. “A Shanghai Model?” New Left Review 65 (October-November 2010).

Arnold, David. Everyday Technology: Machines and the Making of India's Modernity. Chicago: The University of Chicago Press, 2013.

Blecher, Marc, and Vivienne Shue. Tethered Deer: Government and Economy in a Chinese County, 63-85. Stanford: Stanford University Press, 1996.

Breen, Timothy H. American Insurgents, American Patriots: The Revolution of the People. New York: Hill and Wang, 2010.

Brewer, John, and Roy Porter, eds. Consumption and the World of Goods. New York: Routledge, 1994.

Bruun, Ole. Business and Bureaucracy in a Chinese City: An Ethnography of Private Business Households in Contemporary China, 48. Berkeley: Institute of East Asian Studies, 1991.

Cao, Nanlai. Constructing China's Jerusalem: Christians, Power, and Place in Contemporary Wenzhou. Stanford: Stanford University Press, 2010.

Cirincione, Joseph. Bomb Scare: The History and Future of Nuclear Weapons, 51. New York: Columbia University Press, 2007.

Clunas, Craig. Superfluous Things: Material Culture and Social Status in Early Modern China. Champaign: University of Illinois Press, 1991.

Cochran, Sherman. Big Business in China: Sino-Foreign Rivalry in the Cigarette Industry, 1890-1930. Cambridge: Harvard University Press, 1980.

56Eleanor Albert. 2018. "Christianity in China." Council on Foreign Relations. https://www.cfr.org/backgrounder/christianity-china. Accessed 15 August 2018.

${ }^{57}$ On the co-optation of Christianity and Christian holidays and rituals, see Nanlai Cao. 2010. Constructing China's Jerusalem: Christians, Power, and Place in Contemporary Wenzhou. Stanford: Stanford University Press. 
Craig, Steve. Out of the Dark: A History of Radio and Rural America. Tuscaloosa: University of Alabama Press, 2009.

Dao, Wen interview of Gan Jing. "Hangzhou diyiwei getihu" (The First getibu in Hangzhou). Hangzhou ribao, 16 March 2016. http://hzdaily.hangzhou.com. $\mathrm{cn} / \mathrm{hzrb} / \mathrm{html} / 2016-03 / 16 /$ content_2217432.htm. Consulted 16 April 2017.

Diamant, Neil Jeffrey. Revolutionizing the Family: Politics, Love, and Divorce in Urban and Rural China, 1949-1968. Berkeley: University of California Press, 2000.

Dikötter, Frank. The Cultural Revolution: A People's History, 1962-1976. New York: Bloomsbury Press, 2017.

Fewsmith, Joseph. Dilemmas of Reform in China: Political Conflict and Economic Debate. Armonk: M. E. Sharpe, 1994.

Frank, Dana. Buy American: The Untold Story of Economic Nationalism. Boston: Beacon Press, 1999.

French, Paul and Matthew Crabbe. Fat China: How Expanding Waistlines Are Changing a Nation. London: Anthem Press, 2010.

Friedman, Edward, Paul G. Pickowicz, and Mark Selden. Revolution, Resistance, and Reform in Village China. New Haven: Yale University Press, 2005.

Gerth, Karl. China Made: Consumer Culture and the Creation of the Nation. Cambridge: Harvard University Press, 2003.

Gerth, Karl. "Lifestyles of the Rich and Infamous: The Creation and Implication of China's New Aristocracy." In special issue of Comparative Sociology 10, no. 4 (2011): 488-507.

Gerth, Karl. As China Goes, So Goes the World: How Chinese Consumers Are Transforming Everything. New York: Farrar, Straus and Giroux, 2013.

Gerth, Karl. "Driven to Change: The Chinese State-Led Development of a Car Culture and Economy." In Energy Transport in Green Transition: Perspectives on Ecomodernity, edited by Atle Middledun and Nina Witoszek. New York: Routledge, 2015.

Glickman, Lawrence B. Buying Power: A History of Consumer Activism in America. Chicago: The University of Chicago Press, 2009.

Gold, T. B. "Urban Private Business and China's Reforms." In Reform and Reaction in Post-Mao China: The Road to Tiananmen, edited by Richard Baum, 84-103. New York: Routledge, 1991.

Goodman, Ruth. How to Be a Victorian: A Dawn-to-Dusk Guide to Victorian Life. London: Viking, 2015.

Grey, Jack. Mao Tse-tung, 46-47. Cambridge: Lutterworth Press, 1973.

Guanren, Chen. "Wenge' you Zhongguo shoujia siying fandian: Yuebin fandian” (Yuebin Restaurant, the First Privately Owned Restaurant in China After the 'Cultural Revolution'), initially published in Zhongwai shu zhai 3 (2005): 3235. www.zwszzz.com/DCFB/bkview.asp?bkid=191395\&cid=630477. 
Harrison, Henrietta. China: Inventing the Nation. New York: Oxford University Press, 2011.

Hart-Landsberg, Martin, and Paul Burkett. China and Socialism: Market Reforms and Class Struggle. New York: Monthly Review Press, 2005.

Hewitt, Brad, and James Moline. Your New Money Mindset: Create a Healthy Relationship with Money. iBook, no pagination, 2015.

Huang, Yasheng. Capitalism with Chinese Characteristics. New York: Cambridge University Press, 2008.

Hunwick, Robert Foyle. "Why Christmas Is Huge in China." The Atlantic, December 24, 2014.

Jhally, Sut. Codes of Advertising: Fetishism and the Political Economy of Meaning in the Consumer Society. New York: St. Martin's Press, 2016.

Jun, Guang. "Hang Liu Zhong zhaokai jiazhang hui" (A Parents' Meeting in Hangzhou No. 6 Middle School). Hangzhou Daily, March 27, 1957.

Lasch, Christopher. Culture of Narcissism: American Life in an Age of Diminishing Expectations. New York: Warner Books, 2018.

Lee, Lily Xiao Hong, ed. Biographical Dictionary of Chinese Women, 198-200. Armonk: M. E. Sharpe, 1998.

Lingxu, Wang, ed. Ziyou guodu: gongshang getihu shenghuo jishi (A Land of Freedom-A Record of the Business getihu Economy). Shanghai: Shanghai Academy of Social Sciences Press, 1993.

McEwen, Susan. "New Kids on the Block." China Business Review 21, no. 3 (May-June 1994): 35-39.

Nan, Wu. "Gaige kaifang hou de xiahai jingshang yanjiu" (A Study of the Trends of Going into Business After the Start of the Reform and Opening Era). M.A. thesis, Liaoning University, 2011.

Naughton, Barry. Growing Out of the Plan: Chinese Economic Reform, 19781993. Cambridge: Cambridge University Press, 1995.

Nee, Victor, and Sonja Opper. Capitalism from Below: Markets and Institutional Change in China. Cambridge: Harvard University Press, 2012.

Perry, Elizabeth, and Li Xun. Proletarian Power: Shanghai in the Cultural Revolution. Boulder: Westview Press, 1997.

Pittaway, Mark. Eastern Europe, 1939-2000. London: Hodder Arnold, 2004.

Qiuhang, Wang. "Yihuang sanshi nian, fangfu jiu zai yanqian" (Everything Still Remembered Vividly After 30 Years). Lao Zhaopian, no. 99 (2015): 73-83. Shandong: Shandong huabao chubanshe.

Reinhardt, Anne. Navigating Semi-Colonialism: Shipping, Sovereignty, and Nation-Building in China, 1860-1937. Cambridge: Harvard University Press, 2018.

Rhoads, Edward J. M. "Cycles of Cathay: A History of the Bicycle in China." Transfers 2, no. 2 (Summer 2012): 95-120. 
Riskin, Carl. China's Political Economy: The Quest for Development Since 1949. Oxford: Oxford University Press, 1987.

Sanchez-Sibony, Oscar. Red Globalization: The Political Economy of the Soviet Cold War from Stalin to Khrushchev, 9. Cambridge: Cambridge University Press, 2014.

Schlesinger, Arthur M. The Colonial Merchants and the American Revolution, 1763-1776. New York: Frederick Ungar, 1957 [1918].

Schoenhals, Michael. Doing Things with Words in Chinese Politics: Five Studies. Berkeley: Center for Chinese Studies, Institute of East Asian Studies, University of California, 1992.

Solinger, Dorothy J. "Commerce: The Petty Private Sector and the Three Lines on the Early 1980s." In Three Visions of Chinese Socialism, edited by Dorothy J. Solinger, 73-111. Boulder: Westview Press, 1984.

Swett, Pamela E., S. Jonathan Wiesen, and Jonathan R. Zatlin, eds. Selling Modernity: Advertising in Twentieth-Century Germany. Durham: Duke University Press, 2007.

Teiwes, Frederick, and Warren Sun. Paradoxes of Post-Mao Rural Reform: Initial Steps Toward a New Chinese Countryside, 1976-1981. New York: Routledge, 2015.

Teiwes, Frederick, and Warren Sun. The End of the Maoist Era: Chinese Politics During the Twilight of the Cultural Revolution, 1972-1976. Armonk: M. E. Sharpe, 2007.

Thompson, E. P. “Time, Work-Discipline, and Industrial Capitalism.” Past \& Present 38 (1967): 56-97.

Trentmann, Frank. Empire of Things: How We Became a World of Consumers, from the Fifteenth Century to the Twenty-First. London: Penguin Books, 2017.

Tungate, Mark. Adland: A Global History of Advertising, Ed. 2. Philadelphia: Kogan Page, 2013.

Unger, Jonathan. The Transformation of Rural China. Armonk, NY: M.E. Sharpe, 2002.

Walder, Andrew. China Under Mao: A Revolution Derailed, 331. Cambridge: Harvard University Press, 2015.

Young, Susan. Private Business and Economic Reform in China, 6. New York: Routledge, 1995.

Yu, Miin-ling. "Labor Is Glorious"”: Model Laborers in the People's Republic of China." In China Learns from the Soviet Union, 1949-Present, edited by Thomas P. Bernstein and Hua-Yu Li. Lanham: Lexington Books, 2010.

Yuanhang, Ren. "Qian yao yong zai daokou shang” (Money Ought to Be Spent on the Blade). Hangzhou Daily, August 22, 1957.

Yuanhang, Ren. "Shucai diqi bufen nongmin zizhang langfei xianxiang" (The Phenomenon of Vegetable Farmers Overspending). Hangzhou Daily, July 25, 1957. 
Yudkin, Marcia. Making Good: Private Business in Socialist China, 30. Beijing: Foreign Languages Press, 1986.

Zeng, Xiaowei. "Market Transition, Wealth and Status Claims." In The New Rich in China: Future Rulers, Present Lives, edited by David S. G. Goodman, 5370. London: Routledge, 2008.

Zhanliang, Zhu. "Shanghai qinggongye mingpai chanpin chutan" (A Brief Analysis of Famous Brands Produced by Shanghai Light Industry). Shanghai jingji yanjiu 9, no. 9 (1981): 7-11.

Zhou, Kate Xiao. How the Farmers Changed China: Power of the People. Boulder: Westview Press, 1996.

Open Access This chapter is licensed under the terms of the Creative Commons Attribution 4.0 International License (http://creativecommons.org/licenses/ by $/ 4.0 /$ ), which permits use, sharing, adaptation, distribution and reproduction in any medium or format, as long as you give appropriate credit to the original author(s) and the source, provide a link to the Creative Commons license and indicate if changes were made.

The images or other third party material in this chapter are included in the chapter's Creative Commons license, unless indicated otherwise in a credit line to the material. If material is not included in the chapter's Creative Commons license and your intended use is not permitted by statutory regulation or exceeds the permitted use, you will need to obtain permission directly from the copyright holder.

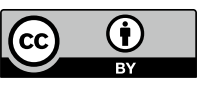

